Journal of Epidemiology and Public Health (2019), 4(3): 234-246

https://doi.org/10.26911/jepublichealth.2019.04.03.11

\title{
Factors Associated with Pneumonia in Children Under Five after Earthquake: A Path Analysis Evidence from West Nusa Tenggara, Indonesia
}

\author{
Nur Isniani Ningsih'), Harsono Salimo²), Setyo Sri Rahardjo3) \\ 1)Masters Program in Public Health, Universitas Sebelas Maret, Surakarta \\ 2)Department of Pediatrics, Dr. Moewardi Hospital, Surakarta \\ 3) Faculty of Medicine, Universitas Sebelas Maret
}

\begin{abstract}
Background: Pneumonia is an infectious disease which is the main killer among children under five. This study aims to analyze socio-economic and environmental determinants of the incidence of pneumonia in children under five after the earthquake.

Subjects and Method: This study used observational analytic using case control. The total sample of 237 children under five aged 12-59 months old and the sampling technique was fixed disease sampling. The independent variables in this study were birth weight, exclusive breastfeeding, nutritional status, immunization status, maternal education, family income, healthy behavior, physical quality of the house, exposure to cooking fuel smoke, smoking activities of family members and active village influences. Collecting the variables was through questionnaires and analyzed by using path analysis.

Results: Birth weight ( $b=-1.92 ; 95 \% \mathrm{CI}=-3.34$ to $-0.49 ; \mathrm{p}=0.008)$, exclusive breastfeeding $(\mathrm{b}=-$ $1.41 ; 95 \% \mathrm{CI}=-2.43$ to $-0.37 ; \mathrm{p}=0.007)$, nutritional status $(\mathrm{b}=-2.98 ; 95 \% \mathrm{CI}=-4.10$ to $-1.86 ; \mathrm{p}<0.001)$, immunization status $(\mathrm{b}=-1.45 ; 95 \% \mathrm{CI}=-2.51$ to $-0.40 ; \mathrm{p}=0.007)$, maternal education $(\mathrm{b}=-1.46$; $95 \% \mathrm{CI}=-2.63$ to $-0.28 ; \mathrm{p}=0.014)$, family income $(\mathrm{b}=-1.86 ; 95 \% \mathrm{CI}=-3.32$ to-0.41; $\mathrm{p}=0.012)$, healthy behavior $(b=-1.24 ; 95 \% \mathrm{CI}=-2.28$ to $-0.21 ; \mathrm{p}=0.018)$, physical quality of the house $(\mathrm{b}=-1.16 ; 95 \% \mathrm{CI}=$ -2.20 to $-0.11 ; \mathrm{p}=0.030)$, and active standby village strata $(\mathrm{b}=-1.25 ; 95 \% \mathrm{CI}=-2.49$ to -0.12 ; $\mathrm{p}=0.048$ ) can reduce the incidence of pneumonia in children under five. Smoking activities of family members $(b=1.38 ; 95 \% \mathrm{CI}=0.02$ to $2.73 ; \mathrm{p}=0.045)$ and exposure to cooking fuel smoke $(\mathrm{b}=1.46 ; 95 \% \mathrm{CI}=0.34$ to $2.51 ; \mathrm{p}=0.010)$ can increase the incidence of pneumonia in children under five.

Conclusion: The decrease in the incidence of pneumonia was influenced directly by healthy behavior, immunization status, nutritional status, physical quality of the house, exclusive breastfeeding, birth weight, and active standby village strata. Family smoking activities and smoke exposure to cooking fuel can increase the incidence of pneumonia in children under five.
\end{abstract}

Keywords: Pneumonia, socioeconomic, village strata, path analysis

\section{Correspondence:}

Nur Isniani Ningsih. Masters Program in Public Health, Universitas Sebelas Maret. Jl. Ir. Sutami 36A, Surakarta 57126, Central Java. Email: isniani2193@gmail.com. Mobile: o81997998692.

\section{BACKGROUND}

Pneumonia is an infectious disease that is the main killer for children under five. This infectious disease caused by bacteria, viruses, and fungi. Pneumonia in children under five will have an impact on the long term that will appear in adulthood, which is a decrease in lung function. Unfortunately, this disease did not received much attention (Dean and Florin, 2018; WHO, 2014)

The prevalence of pneumonia in children under five in Indonesia in 2015 was to 554,650 people (2.3\%) and 2016 with the number of cases by 503,738 (2.1\%). In $2016,28.07 \%$ of the target of $30 \%$ was reached. The strategic plan indicator used is 
the percentage of districts/cities where 50\% of health centers conduct examination and management of pneumonia using the IMCI program (Integrated Management of sick children). The mortality rate from pneumonia in the 1-4 years old age group is slightly higher at $0.13 \%$ compared to the baby group of $0.06 \%$ (Ministry of Health, 2018).

Data from the Indonesian Ministry of Health (2018) reports the highest cases of pneumonia in Indonesia in West Nusa Tenggara Province with a percentage of 6.38\%, followed by Bangka Belitung Islands at $6.05 \%$, South Kalimantan $5.53 \%$ and Central Sulawesi 5.19\%. In 2016 the incidence of pneumonia in NTB increased by 32,536 children under five from 33,291 children under five, while 27,513 cases were treated (84.56\%). East Lombok is the highest district with pneumonia cases, which is 8.253 cases in infants (NTB Province, 2018).

Triangular model of infection pneumonia risk factors occur due to an imbalance in the interaction between several components or risk factors, namely the causative agent, host, and environment including the community environment including a history of low birth weight (LBW), inadequate breastfeeding history, malnutrition, incomplete immunization status, indoor air pollution originating from the use of biomass as cooking fuel or the presence of family members who smoke, the physical quality of houses that do not fulfill health requirements, low regional economic status, maternal healthy behavior, and population density (occupancy) (FAO et al., 2016; Nguyen et al., 2017). Socio-economic and educational status indirectly influences health which is related to the incidence of pneumonia in infants (Mosley and Chen, 2003; Machmud, 2009).

Indonesia is a disaster-prone country in terms of geographical, climatological and demographic aspects. Disasters in Law No. 24 of 2007 are defined as incidents that threaten and disturb people's lives caused by natural factors or non-natural factors or human factors, resulting in fatalities, environmental damage, property losses, and psychological impacts.

The earthquake that occurred in the Province of West Nusa Tenggara on August 5, 2018 with a strength of 7 on the Richter scale in particular has devastated East Lombok, North Lombok and the City of Mataram. The National Disaster Management Agency (BNPB) noted that the earthquake that occurred in Lombok caused 515 people to die, 7,145 people injured, 431,416 people displaced, the number of houses damaged were 73,843 units and 798 public and social facilities (Nugroho, 2018).

Post-earthquake has an effect on public health status, especially children under five. The impact of the earthquake can be placed into three basic categories, namely health, socio-economic, and environmental damage. The most common diseases after the earthquake were respiratory tract infections followed by skin diseases and diarrhea (Marx and Phalkey, 2012).

Control of pneumonia required health promotion efforts to improve the ability of the community to live healthy and be able to develop health and create a conducive environment. The goals of health promotion in pneumonia include primary goals (mother and children under five family), secondary targets (health workers and crosssectoral officers), and tertiary targets (decision making) (Ministry of Health, 2018).

This study aimed to analyze socioeconomic and environmental determinants of the incidence of pneumonia in children under five after the earthquake. 
Journal of Epidemiology and Public Health (2019), 4(3): 234-246

https://doi.org/10.26911/jepublichealth.2019.04.03.11

\begin{tabular}{l}
\hline SUBJECTS AND METHOD \\
\hline a. Study Design \\
This study was a case control conducted at \\
five health centers, Lombok, West Nusa \\
Tenggara, from April to May 2019.
\end{tabular}

\section{b. Population and Sample}

The target population was chidlren aged 1259 months old in Aikmel, Suela, Batu, Sembalun, and Labuhan Lombok health centers. A sample of 237 children was selected by fixed disease sampling.

\section{c. Study Variables}

The dependent variable was pneumonia. The independent variables were birth weight, exclusive breastfeeding, nutritional status, immunization status, maternal education, family income, physical quality of the house, healthy behavior, smoke exposure to cooking fuel, smoking activities of family members, and active standby village influences.

\section{d. Operational Definition of Variables}

Pneumonia was a respiratory tract infection that affected the lung tissue (alveoli) with the pull of the lower chest wall in, the frequency of rapid breathing aged12-59 months old for 40 times or more, seen from the results of rotgen photographs and patient laboratories. Diagnosis of pneumonia patients was recorded in the medical record book and has been determined by trained doctors/ paramedics based on the integrated management of healthy children under five guidebook.

Birth weight is the baby's weight at birth regardless of the normal gestational age if the weight is 2500-400og. The data was measured by weight scale.

Exclusive breastfeeding was breastfeeding from birth to 6 months old without additional food, unless there was a drug or vaccine with medical indications obtained by asking the mother directly. The data were collected by questionnaire.
Nutritional status was the nutritional condition of children aged 12-59 months old measured by body weight index according to age (WAZ).

Immunization status was the complete whether the children get immunization that have been scheduled according to their age based on the immunization schedule. The data were collected by questionnaire. The measurement scale was dichotomous.

Education was the highest level of formal education successfully completed by the mother. The data were collected by questionnaire. The measurement scale was categorical.

Family income was the amount of income received by the main family (husband, wife, children who have worked) produced every month, which is expressed in rupiah. The data were collected by questionnaire.

The physical quality of the house was condition of the physical environment of a healthy home seen from the layout, the condition of the ceiling, walls, floors, room windows, ventilation, kitchen smoke holes, lighting, and solids. The data were collected by questionnaire.

Healthy behavior was an activity that can be observed or can not be observed relating to the maintenance and improvement of health. The data were collected by questionnaire.

Smoke exposure to cooking fuel was exposure to smoke in the home that comes from burning wood, charcoal, husks, oil, and other biomass. The data were collected by questionnaire.

Smoking activity of family member was family members who have a habit of smoking inside the house. The data were collected by questionnaire.

Village strata was active alert village levels in the Regency. The data were collected by questionnaire. 


\section{e. Data Analysis}

Univariate analysis described the characteristics of variables. Bivariate analysis in the study was conducted to determine the relationship between independent variables and the dependent variable by using the chisquare test. Multivariate analysis used path analysis to determine the magnitude of the influence directly or indirectly of a variable.

\section{f. Research Ethics}

Research ethics in this study include approval sheets, anonymity, confidentiality, and ethical feasibility. Ethical feasibility in this study came from the Health Research Ethics Committee of Dr. Moewardi Hospital Surakarta with number: 327/ III / HREC / 2019.

\begin{tabular}{l} 
RESULTS \\
\hline 1. Univariate Analysis \\
Tables 1 and 2 showed the characteristics of \\
respondents and other variables, using con- \\
tinuous data and categorical data.
\end{tabular}

Table 1. Sample characteristics (continuous data)

\begin{tabular}{llcccc}
\hline \multicolumn{1}{c}{ Independent Variables } & (n) & Mean & SD & Min & Max \\
\hline Family income (Rupiah) & 237 & 933.9 & 119.8 & 650,000 & $1,400,000$ \\
Birth weight(gram) & 237 & 2930 & 462.2 & 1800 & 4500 \\
Nutritional status(kg) & 237 & 10.2 & 1.7 & 6.3 & 14.6 \\
Exposure to cooking fuel smoke & 237 & 3.6 & 0.8 & 2.0 & 5.0 \\
Physical quality of the house & 237 & 12.2 & 2.8 & 7.0 & 17.0 \\
\hline
\end{tabular}

\section{Bivariate Analysis}

Table 3 showed the results of bivariate analysis between the dependent variable and the independent variable.

There was a relationship between maternal education and the incidence of pneumonia. Children from mothers who have higher education have a lower risk of pneumonia compared to children from low-educated mothers $(\mathrm{OR}=0.20 ; \mathrm{p}<0.001)$.

There was a relationship between family income and the incidence of pneumonia. Children from high income families have a lower risk of pneumonia compared to children who have low income families (OR = 0.11; $\mathrm{p}<0.001)$.

There was a relationship between histories of birth weight with pneumonia. Children with a history of normal birth weight have a lower risk of pneumonia than children with a history of low birth weight (OR= 0.04; $\mathrm{p}<0.001)$.

There was a relationship between smoke exposure to cooking fuel and pneumonia. Children who were exposed to cook- ing fuel smoke have a higher risk of pneumonia compared to unexposed children $(\mathrm{OR}=2.89 ; \mathrm{p}<0.001)$.

There was an association of exclusive breastfeeding with the incidence of pneumonia. Children with exclusive breastfeeding have a lower risk of pneumonia compared to children who were not exclusively breastfed $(\mathrm{OR}=0.13 \mathrm{p}<0.001)$.

There was a relationship between nutritional status and the incidence of pneumonia. Children with good nutritional status had a lower risk of pneumonia compared to children who had poor nutritional status (OR $=0.52 ; \mathrm{p}<0.001)$.

There was a relationship between immunization status and the incidence of pneumonia. Children with complete immunization status have a lower risk of experiencing pneumonia compared to children with incomplete immunization status $(\mathrm{OR}=$ 0.28; $\mathrm{p}<0.001)$.

There was a relationship between healthy behavior and the incidence of pneumonia. Children under five from 
Journal of Epidemiology and Public Health (2019), 4(3): 234-246

https://doi.org/10.26911/jepublichealth.2019.04.03.11

healthy mothers had a lower risk of pneumonia compared to children under five from mothers who had unhealthy behavior $(\mathrm{OR}=0.19 ; \mathrm{p}<0.001)$.

There was a correlation between family smoking activity and the incidence of pneumonia. Children from families who smoke have a higher risk of pneumonia than children from non-smoking families $(\mathrm{OR}=7.98 ; \mathrm{p}<0.001)$.

Table 2. Sample characteristics (categorical data)

\begin{tabular}{|c|c|c|}
\hline Characteristics & Frequency (n) & Percentage (\%) \\
\hline \multicolumn{3}{|c|}{ Children under five Pneumonia Status } \\
\hline Non pneumonia & 158 & 66.7 \\
\hline Pneumonia & 79 & 33.3 \\
\hline \multicolumn{3}{|l|}{ Maternal education } \\
\hline Low $<$ HS & 86 & 36.3 \\
\hline High $\geq$ HS & 151 & 63.7 \\
\hline \multicolumn{3}{|l|}{ Family income } \\
\hline Low $<900,000$ & 67 & 28.3 \\
\hline High $\geq 900,000$ & 170 & 71.7 \\
\hline \multicolumn{3}{|l|}{ Smoke exposure to Cooking Fuel } \\
\hline Not exposed & 131 & 55.3 \\
\hline Exposed & 106 & 44.7 \\
\hline \multicolumn{3}{|l|}{ History of birth weight } \\
\hline LBW $<2500$ gram & 44 & 18.6 \\
\hline Normal $\geq 2500-4000$ gram & 193 & 81.4 \\
\hline \multicolumn{3}{|l|}{ Exclusive breastfeeding } \\
\hline No & 73 & 30.8 \\
\hline Yes & 164 & 69.2 \\
\hline \multicolumn{3}{|l|}{ Nutritional status } \\
\hline Lack of nutrition & 78 & 32.9 \\
\hline Good nutrition & 159 & 67.1 \\
\hline \multicolumn{3}{|l|}{ Immunization Status } \\
\hline Incomplete & 102 & 43 \\
\hline Complete & 135 & 57 \\
\hline \multicolumn{3}{|l|}{ Healthy behavior } \\
\hline Bad behavior & 89 & 37.6 \\
\hline Good behavior & 148 & 62.4 \\
\hline \multicolumn{3}{|l|}{ Family Smoking Activity } \\
\hline Not smoking & 89 & 37.6 \\
\hline Smoking & 148 & 62.4 \\
\hline \multicolumn{3}{|l|}{ Physical Quality of Houses } \\
\hline Poor physical quality of the house & 126 & 53.2 \\
\hline Good physical quality of the house & 111 & 46.8 \\
\hline \multicolumn{3}{|l|}{ Village strata } \\
\hline Pratama & 189 & 79.7 \\
\hline Madya & 19 & 8.0 \\
\hline Purnama & 6 & 2.5 \\
\hline Mandiri & 23 & 9.7 \\
\hline
\end{tabular}




\section{Path Analysis}

\section{a. Model Specification}

Model specifications described the relationship between the variables studied. In this study there were measurable variables, namely birth weight, exclusive breastfeeding, nutritional status, immunization status, maternal education level, family income, physical quality of the house, healthy behavior, exposure to cooking fuel smoke, family smoking activities, the influence of active village strata, and the incidence of pneumonia.

\section{b. Model Identification}

Measured variable include:
1) Measured variable
$=12$
2) Endogenous variable
$=5$
3) Exogenous variable
$=7$
4) Total parameter
$=16$

Degree of freedom $(\mathrm{df})=$ (number of measured variables $\mathrm{x}$ (number of measured variables +1$) / 2)$ - (endogenous variable + exogenous variable+number of parameters) $=(12 \times(12+1) / 2)-(5+7+16)$ $=78-28=50$

The result of the degree of freedom (df) was 50, which mean that over identified or path analysis can be done.

Table 3 showed the results of path analysis. There was a direct relationship between healthy behavior and the risk of children experiencing pneumonia. Children who have mothers with healthy behavioral have logodd to experience pneumonia by 1.24 units lower than mothers with unhealthy behavior $(\mathrm{b}=-1.24 ; 95 \% \mathrm{CI}=-2.28$ to -0.21; $\mathrm{p}=0.018$ ).

There was a direct relationship between exposure to smoke from cooking fuel and the risk of a child experiencing pneumonia. Children who were exposed to smoke from cooking fuel have logodd to experience pneumonia by 1.43 units higher than children who were not exposed to cooking fuel smoke $(b=1.43 ; 95 \% \mathrm{CI}=0.34$ to $2.51 ; \mathrm{p}=0.010$ ).

There was a direct relationship between immunization status and the risk of pneumonia in children. Children with complete immunization status have logodd to experience pneumonia by 1.45 units higher than incomplete immunization status $(\mathrm{b}=-$ 1.45; 95\% CI=-2.51 to $-0.40 ; \mathrm{p}=0.007$ ).

There was a direct relationship between nutritional status and the risk of pneumonia in children. Children with good nutritional status have logodd to have pneumonia by 2.98 units lower than malnutrition $(b=-2.98$; 95\% $\mathrm{CI}=-4.10$ to -1.86 ; $\mathrm{p}<0.001)$.

There was a direct relationship between the physical quality of the home and the risk of pneumonia in children. Children with physical qualities of houses that fulfilled the requirements of a healthy house having logodd to have pneumonia by 1.16 units lower than poor physical quality of the house $(b=-1.16 ; 95 \% \mathrm{CI}=-2.20$ to $-0.11 ; \mathrm{p}=$ o.030).

There was a direct relationship between exclusive breastfeeding and the risk of pneumonia in children. Children with exclusive breastfeeding had logodd to experience pneumonia by 1.40 units lower than children without exclusive breastfeeding ( $\mathrm{b}=-1.41 ; 95 \% \mathrm{CI}=-2.43$ to -0.37 ; $\mathrm{p}=0.007)$.

There was a direct relationship between the history of birth weight and the risk of the pneumonia in children. Children with a history of normal birth weight have logodd to have pneumonia by 1.92 units lower than children with a history of low birth weight $(b=-1.92 ; 95 \% \mathrm{CI}=-3.34$ to $0.49 ; \mathrm{p}=0.008$ ).

There was a direct relationship between family smoking activities and the risk of children experiencing pneumonia. Children who were exposed to cigarette smoke have logodd to experience pneu- 
Journal of Epidemiology and Public Health (2019), 4(3): 234-246

https://doi.org/10.26911/jepublichealth.2019.04.03.11

monia by 1.38 units higher than those who were not exposed to cigarette smoke $(\mathrm{b}=$ 1.38 ; $95 \% \mathrm{CI}=0.02$ to 2.73 ; $\mathrm{p}=0.045$ ).

There was a direct relationship between village strata and the risk of pneumonia in children, children with high village strata have logodd to experience pneumonia by 1.25 units lower than low strata $(b=-1.25$; $95 \% \mathrm{CI}=-2.49$ to $-0.12 ; \mathrm{p}=0.048$ ).

Maternal education was indirectly related to the risk of children experiencing pneumonia through family income and healthy behavior.

Family income was indirectly related to the risk of children experiencing pneumonia through complete immunization status, nutritional status, good physical quality of the home, and family smoking activities.

Healthy behavior related indirectly to the risk of children under five experiencing pneumonia through family smoking activities.

Table 3. Bivariate analysis of the incidence of pneumonia among children under five

\begin{tabular}{|c|c|c|c|c|c|c|c|c|}
\hline \multirow{3}{*}{$\begin{array}{l}\text { Independent } \\
\text { Variables }\end{array}$} & \multicolumn{4}{|c|}{ Pneumonia } & \multirow{2}{*}{\multicolumn{2}{|c|}{ Total }} & \multirow{3}{*}{ OR } & \multirow{3}{*}{$\mathbf{p}$} \\
\hline & \multicolumn{2}{|c|}{ No } & \multicolumn{2}{|c|}{ Yes } & & & & \\
\hline & $\mathbf{N}$ & $\%$ & $\mathbf{N}$ & $\%$ & $\mathbf{N}$ & \% & & \\
\hline \multicolumn{9}{|l|}{ Maternal education } \\
\hline Low & 38 & 44.2 & 48 & 55.8 & 86 & 100 & \multirow[t]{2}{*}{0.20} & \multirow[t]{2}{*}{$<0.001$} \\
\hline High & 120 & 79.5 & 31 & 20.5 & 151 & 100 & & \\
\hline \multicolumn{9}{|l|}{ Income } \\
\hline Low & 21 & 31.3 & 46 & 68.7 & 67 & 100 & \multirow[t]{3}{*}{0.11} & \multirow[t]{2}{*}{$<0.001$} \\
\hline High & 137 & 80.6 & 33 & 19.4 & 170 & 100 & & \\
\hline \multicolumn{8}{|l|}{ Birth weight } & \\
\hline LBW & 6 & 13.6 & 38 & 86.4 & 44 & 100 & \multirow[t]{2}{*}{0.04} & \multirow[t]{2}{*}{$<0.001$} \\
\hline Normal & 152 & 78.8 & 41 & 21.2 & 193 & 100 & & \\
\hline \multicolumn{9}{|l|}{ Smoke exposure to } \\
\hline Cooking Fuel & & & & & & & & \\
\hline Not exposed & 101 & 77.1 & 30 & 22.9 & 131 & 100 & \multirow[t]{3}{*}{2.89} & \multirow[t]{2}{*}{$<0.001$} \\
\hline Exposed & 57 & 53.8 & 49 & 46.2 & 106 & 100 & & \\
\hline \multirow{2}{*}{\multicolumn{9}{|c|}{$\begin{array}{l}\text { Exclusive } \\
\text { breastfeeding }\end{array}$}} \\
\hline & & & & & & & & \\
\hline No & 26 & 35.6 & 47 & 64.4 & 73 & 100 & \multirow[t]{3}{*}{0.13} & \multirow[t]{2}{*}{$<0.001$} \\
\hline Yes & 132 & 80.5 & 32 & 19.5 & 164 & 100 & & \\
\hline \multicolumn{8}{|l|}{ Nutritional status } & \\
\hline Lack of nutrition & 20 & 25.6 & 58 & 74.4 & 78 & 100 & \multirow[t]{3}{*}{0.52} & \multirow[t]{2}{*}{$<0.001$} \\
\hline Good nutrition & 138 & 86.8 & 21 & 13.2 & 159 & 100 & & \\
\hline \multicolumn{8}{|c|}{ Immunization Status } & \\
\hline Incomplete & 45 & 44.1 & 57 & $55 \cdot 9$ & 102 & 100 & \multirow[t]{2}{*}{0.15} & $<0.001$ \\
\hline Complete & 113 & 83.7 & 22 & 16.3 & 135 & 100 & & \\
\hline Healthy behavior & & & & & & & & \\
\hline Bad behavior & 39 & 43.8 & 50 & 56.2 & 89 & 100 & 0.19 & $<0.001$ \\
\hline Good behavior & 119 & 80.4 & 29 & 19.6 & 148 & 100 & & \\
\hline Family Smoking & & & & & & & & \\
\hline Activity & 80 & 89.9 & 9 & 10.1 & 89 & 100 & 7.98 & $<0.001$ \\
\hline Not smoking & 78 & 52.7 & 70 & $47 \cdot 3$ & 148 & 100 & & \\
\hline Smoking & & & & & & & & \\
\hline $\begin{array}{l}\text { Physical Quality of } \\
\text { Houses }\end{array}$ & & & & & & & & \\
\hline Poor & 66 & 52.4 & 60 & 47.6 & 126 & 100 & 0.22 & $<0.001$ \\
\hline Good & 92 & 82.9 & 19 & 17.1 & 111 & 100 & & \\
\hline
\end{tabular}




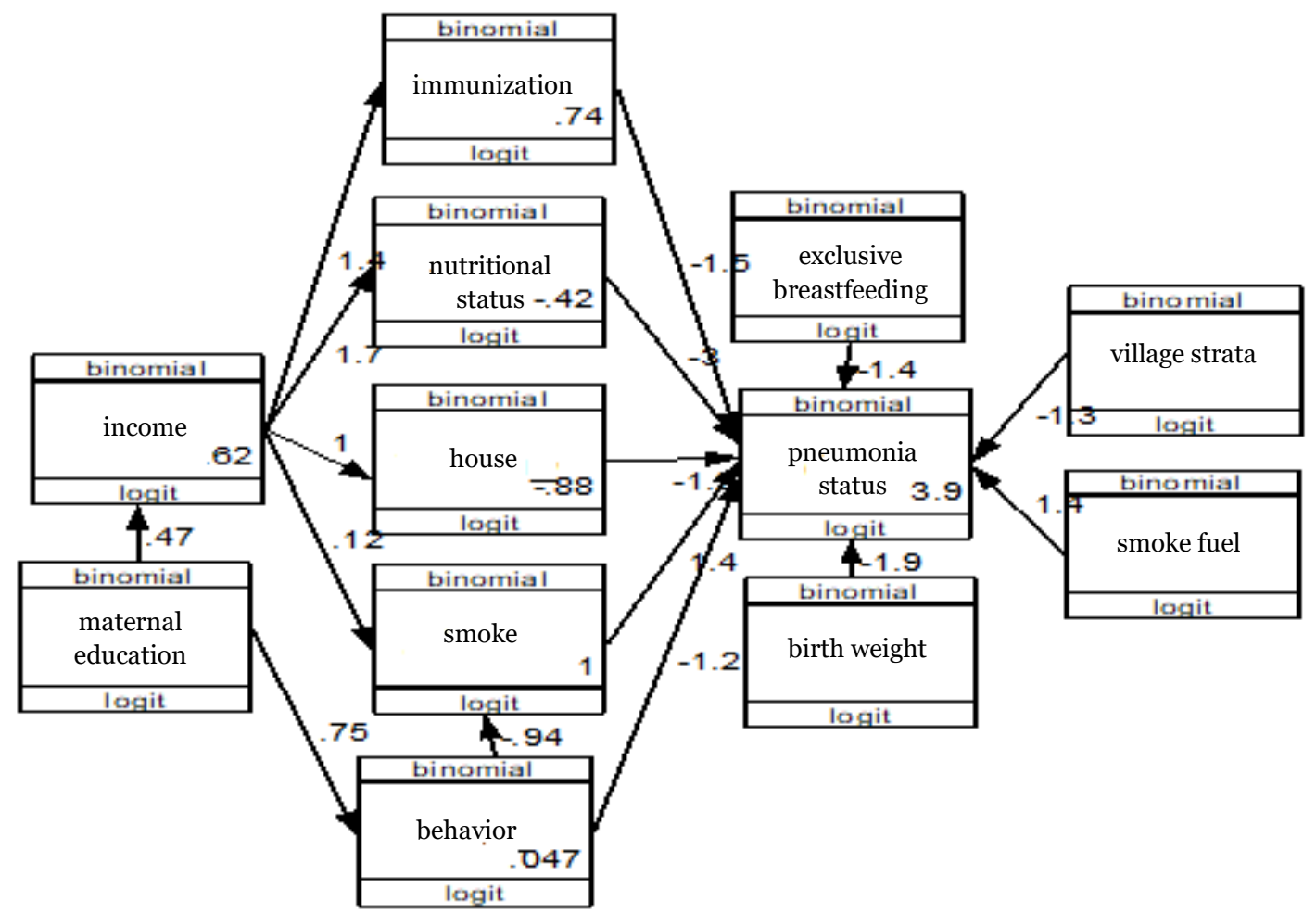

Figure 1. Structural Model of Path Analysis

Table 4. Results of path analysis of the incident of pneumonia in children under five

\begin{tabular}{|c|c|c|c|c|c|}
\hline \multirow{2}{*}{$\begin{array}{l}\text { Dependent } \\
\text { Variables }\end{array}$} & \multirow[b]{2}{*}{ Independent Variables } & \multirow[b]{2}{*}{$\mathbf{b}$} & \multicolumn{2}{|c|}{ CI $95 \%$} & \multirow[b]{2}{*}{$\mathbf{p}$} \\
\hline & & & $\begin{array}{l}\text { Lower } \\
\text { Limit }\end{array}$ & $\begin{array}{l}\text { Upper } \\
\text { Limit }\end{array}$ & \\
\hline \multicolumn{6}{|l|}{ Direct Effect } \\
\hline \multirow{9}{*}{ Pneumonia Status } & $\leftarrow$ Healthy behavior & -1.25 & -2.28 & -0.21 & 0.018 \\
\hline & $\begin{array}{l}\leftarrow \text { Exposure to smoke from } \\
\text { cooking fuel (yes) }\end{array}$ & 1.43 & 0.35 & 2.51 & 0.010 \\
\hline & $\leftarrow$ Immunization status (yes) & -1.46 & -2.51 & -0.40 & 0.007 \\
\hline & $\leftarrow$ Nutritional status (good) & -2.98 & -4.10 & -1.87 & $<0.001$ \\
\hline & $\begin{array}{l}\leftarrow \text { Physical quality of the house } \\
\text { (good) }\end{array}$ & -1.16 & -2.21 & -0.12 & 0.030 \\
\hline & $\leftarrow$ Exclusive breastfeeding & -1.41 & -2.43 & -0.38 & 0.007 \\
\hline & $\leftarrow$ Birth weight $(\geq 2500 g)$ & -1.92 & -3.35 & -0.51 & 0.008 \\
\hline & $\leftarrow$ Family smoking (yes) & 1.38 & 0.03 & 2.73 & 0.045 \\
\hline & $\leftarrow$ Village strata (good) & -1.25 & -2.49 & -0.01 & 0.048 \\
\hline \multicolumn{6}{|l|}{ Indirect Effect } \\
\hline Income & $\leftarrow$ Maternal education $(\geq \mathrm{HS})$ & 0.47 & -0.11 & 1.04 & 0.113 \\
\hline Healthy behavior & $\leftarrow$ Maternal education $(\geq \mathrm{HS})$ & 0.75 & 0.20 & 1.29 & 0.007 \\
\hline Immunization status & $\leftarrow$ Income (high) & 1.44 & 0.84 & 2.04 & $<0.001$ \\
\hline Nutritional status & $\leftarrow$ Income (high) & 1.69 & 1.08 & 2.30 & $<0.001$ \\
\hline $\begin{array}{l}\text { Physical quality of } \\
\text { the house }\end{array}$ & $\leftarrow$ Income (high) & 1.23 & 0.43 & 1.63 & $<0.001$ \\
\hline Family smoking & $\leftarrow$ Income (high) & -0.94 & -0.49 & 0.72 & 0.709 \\
\hline activity & $\leftarrow$ Healthy behavior & & -1.53 & -0.35 & 0.002 \\
\hline \multicolumn{6}{|l|}{ N observation $=237$} \\
\hline Log likehood $=-940$ & & & & & \\
\hline
\end{tabular}


Journal of Epidemiology and Public Health (2019), 4(3): 234-246

https://doi.org/10.26911/jepublichealth.2019.04.03.11

\section{DISCUSSION \\ 1. The effect of birth weight on pneu- monia}

The results showed that there was a significant effect between birth weight and the incidence of pneumonia. Children under five who have a normal birth weight can reduce their risk of pneumonia by 1.92 times compared to children under five with a history of low birth weight $(\mathrm{b}=-1.92 ; 95 \% \mathrm{CI}=-$ 3.34 to $-0.49 ; \mathrm{p}=0.008)$.

Lestari et al. (2017) showed that birth weight was associated with the incidence of pneumonia, children under five with birth weight <2500 grams (LBW) have a risk by 3.24 times greater to experience pneumonia with a value $(\mathrm{OR}=3.14 ; 95 \% \mathrm{CI}=1.34$ to 7.39; $\mathrm{p}=0.008)$.

\section{The effect of exclusive breastfeed- ing on pneumonia}

The results showed that there was a significant effect between exclusive breastfeeding and pneumonia. Children under five who got exclusive breastfeeding have a lower risk of having pneumonia by 1.40 times than children without exclusive breastfeeding $(b=-1.41 ; 95 \% \mathrm{CI}=-2.43$ to 0.37; $\mathrm{p}=0.007$ ).

Breast milk has an important role in determining nutritional status in infants. Breast milk contained lymphocytes and phagocyte immunoglobin antibody, macrophages, lactoferrin, lysozyme, laktoperoxidase, oligosaccharides, bifidus, $\mathrm{C}_{3}$, and $\mathrm{C}_{4}$ factors that can protect babies from infectious diseases, especially respiratory tract infections (Ramezani et al., 2015).

\section{The effect of nutritional status on pneumonia}

The results showed that there was an effect of nutritional status on the incidence of pneumonia. Children under five who have good nutritional status have a lower risk of experiencing pneumonia by 2.98 times than those with less nutritional status $(b=-2.98$;
95\% $\mathrm{CI}=-4.10$ to $-1.86 ; \mathrm{p}<0.001)$. This study was conducted after the earthquake in Lombok. This affected the nutritional status of infants with the discovery of weight loss.

Howie et al. (2016) stated that malnutrition had a strong role and caused an immune system disorder in the occurrence of severe pneumonia with $\mathrm{OR}=8.795 \% \mathrm{CI}$ $=4.2$ to $17.8 ; \mathrm{p}<0.001)$. Nutritional status can indicate immune and immune systems. Iron, zinc, and vitamin A deficiency. Vitamin D levels can increase the occurrence of pneumonia in infants (Zhou et al., 2016).

\section{The effect of immunization status on pneumonia}

The results showed that there was an effect of immunization status on the incidence of pneumonia. Children under five who have complete immunization status have a lower risk of experiencing pneumonia by 1.45 times higher compared to children under five with incomplete immunization status $(b=1.45 ; 95 \% \mathrm{CI}=-2.51$ to $-0.40 ; \mathrm{p}=0.007)$.

This was in line with study by Luthfiyana et al. (2018) which stated that children under five with complete immunization status have a lower risk of developing pneumonia, which was 0.12 times higher compared to children with incomplete immunization status.

\section{The effect of maternal education on pneumonia}

The results of this study indicated that there was an effect of high education and income statistically by 0.46 times lower and maternal healthy behavior by 0.74 times higher than low education.

Maternal education indirectly affected the incidence of pneumonia in children under five and early detection can reduce the incidence of pneumonia in children under five (Pradhan et al., 2016).

\section{The effect of family income on pneumonia}

Family income showed an influence on the 
risk of children experiencing pneumonia through complete immunization status, nutritional status, healthy physical home quality and exposure to smoke from family smoking activities. Luthfiyana et al. (2018) stated that children under five from families who have high income can reduce the risk of pneumonia in children by 0.25 times compared to children under five who have low family income. This study was conducted after the earthquake in Lombok. This affected family income with the discovery of a decrease in income.

Family income was related to the physical quality of the house. The higher the family income, the better the physical quality of the house, which affected the incidence of pneumonia (Norbäck et al., 2019).

\section{The effect of physical quality of house on pneumonia}

The results showed that there was an effect on the physical quality of the house with the incidence of pneumonia. Children under five who have house with healthy physical quality can reduce the risk of pneumonia in infants, which was 1.16 times higher compared to children under five who have unhealthy physical qualities $(b=-1.16 ; 95 \%$ $\mathrm{CI}=-2.20$ to $-0.11 ; \mathrm{p}=0.030$ ).

This study was conducted after the earthquake in Lombok. This affected the physical quality of houses in children under five with the discovery of many houses damaged and living in fines.

Based on the KEPMENKES guideline Number 829/Menkes/SK/VII/1999 concerning residents health requirements including spatial conditions, wall ceilings, floors, bedroom windows, family rooms, ventilation, kitchen smoke holes, lighting, and residential solids.

\section{The effect of healthy behavior on pneumonia}

The results showed that there was an effect of healthy behavior on the incidence of pneumonia. Healthy behavior of hand washing with soap can reduce the incidence of pneumonia by 1.24 times compared to not washing hands with soap $(b=-1.24 ; 95 \%$ $\mathrm{CI}=-2.28$ to $-0.21 ; \mathrm{p}=0.018$ ).

In line with the study conducted by Nikmah et al. (2018) which stated that there was a relationship between the behavior of mothers of washing their hands using soap by 1.41 times lower than the behavior of not washing hands. Good and right hand washing aimed to reduce the number of microorganisms in the hand and prevent spreading to areas that were not contaminated and can reduce the incidence of ARI and pneumonia by 50\% (Ghimire et al., 2012).

\section{The effect of exposure to cooking fuel smoke on pneumonia}

The results of the study showed that there was an influence of smoke exposure on cooking fuel and the incidence of pneumonia. Children under five exposed to cooking fuel smoke have a risk of 1.43 times higher than not exposed to cooking fuel smoke ( $\mathrm{b}=$ 1.46; $95 \% \mathrm{CI}=0.34$ to $2.51 ; \mathrm{p}=0.010$ ).

Mustikarani et al. (2019) stated that children under five who were exposed to smoke from cooking fuel were 1.51 times more likely to increase the incidence of pneumonia compared to infants who were not exposed to cooking fuel. Yunita et al. (2017) stated that children under five who lived in homes which were exposed to smoke from household materials tend to have a greater risk of pneumonia by 5 times than children under five who lived in homes that were not exposed to household smoke. Indoor air pollution can increase the risk of severe pneumonia by increasing the process of infection by pathogenic pneumonia. Exposure to air pollutants contained in biomass fuels increased respiratory tract epithelial attacks and decreased immunity in children under five (PrayGod et al., 2016). 
Journal of Epidemiology and Public Health (2019), 4(3): 234-246

https://doi.org/10.26911/jepublichealth.2019.04.03.11

\section{The effect of family smoking acti- vity on pneumonia}

The results showed that there was an effect of smoke exposure from smoking activity on the incidence of pneumonia. Children under five who were exposed to cigarette smoke have a risk of 1.38 times higher than those who were not exposed to cigarette smoke (b $=1.38 ; 95 \% \mathrm{CI}=0.02$ to $2.73 ; \mathrm{p}=0.045$ ). Children under five were very vulnerable to cigarette smoke (Lima et al., 2016). Exposure to tobacco smoke was the main source of fine particles and inhaled indoors (Pekey et al., 2010).

\section{The effect of village strata on the incidence of pneumonia}

The results showed that there was a direct influence of village strata on the incidence of pneumonia. A good village level can reduce the incidence of pneumonia by 1.25 times lower $(\mathrm{b}=-1.25 ; 95 \% \mathrm{CI}=-2.49$ to $0.12 ; p=0.048)$.

The level of village development related to the availability of health facilities that were available and able to be utilized properly by the community. Lack of access to education and can lead to low levels of education of the local community, thus affecting knowledge about the prevention of pneumonia and utilization of health services (Ayalneh, 2017).

\section{AUTHOR CONTRIBUTION}

Nur Isniani Ningsih, the main author, played a role in collecting and processing the data. Harsono Salimo examined the framework of study concepts and methodology. Setyo Sri Rahardjo reviewed the manuscripts.

FUNDING AND SPONSORSHIP

This study used the authors' independent costs.

\section{CONFLICT OF INTEREST}

There is no conflict of interest in this study.

\section{ACKNOWLEDGMENT}

We would like to thank to the Health Center for assistance the process of this study and the respondents who have participated and were willing to become the respondents.

\section{REFERENCE}

Ayalneh AA, Fetene DM, Lee TJ (2017). Inequalities in health care utilization for common childhood illnesses in Ethiopia: Evidence from the 2011 Ethiopian Demographic and Health Survey. International Journal for Equity in Health. 16(1): 1-9. https://doi.org/10.1186/s12939-017-0561-7

Dean P dan Florin TA (2018). Factors associated with pneumonia severity in children: A systematic review. Journal of the Pediatric Infectious Diseases Society.7(4): 323-334. https://doi.org/10.1093/jpids/piyo46

Editorial I (2012). Invited Editorial: Integrated health, social, and economic impacts of extreme events: evidence, methods, and tools. Global Health Action. 5(1): 19837. https://doi.org/10.3402/gha.v5io.19837

FAO, WHO, Donadio JLS, Shinohara GEM, Rogero MM, Cozzolino SMF, Purniti PS (2016). Paediatrica Indonesiana. Nutrients. 8(4): 207-212. https://doi.org/92 41546123

Lima FEJ, da Mello MJG, Albuquerque M, de FPM de, Lopes MIL, Serra GHC, Lima DEP, Correia JB (2016). Risk factors for community-acquired pneumonia in children under five years of age in the post-pneumococcal conjugate vaccine era in Brazil: A case control study. BMC Pediatrics. 16(1), 1-9. https://doi.org/10.1186/s12887-0160695-6 
Ghimire M, Bhattacharya SK, Narain JP (2012). Pneumonia in South-East Asia Region: public health perspective. The Indian Journal of Medical Research. 135(4): 459-468. Retrieved from http://www.ncbi.nlm.nih.gov/pubmed/22664492

Howie SRC, Schellenberg J, Chimah O, Ideh RC, Ebruke BE, Oluwalana C, Mulholland K (2016). Childhood pneumonia and crowding, bed-sharing and nutrition: a case-control study from The Gambia. The International Journal of Tuberculosis and Lung Disease. 20(10): 1405-1415. https://doi.org/10.5588/ijtld.15.0993

Kemenkes RI (2018). Profile Kesehatan Indonesia Tahun 2017 (Indonesia Health Profile of 2017). In Ministry of Health Indonesia. https://doi.org/10.1002/qj

KEPMENKES Nomor 829/Menkes/SK/$\mathrm{VII} / 1999$.

Lestari N, Salimo H, Suradi (2017). Role of biopsychosocial factors on the risk of pneumonia in children under-five years old at Dr. Moewardi Hospital, Surakarta. Journal of Maternal and Child Health. 02(02): 162-175. https://doi.org/10.26911/thejmch.2017.02.0 2.07.

Luthfiyana NU, Rahardjo SS, Murti B (2018). Multilevel analysis on the biological, social economic, and environmental factors on the risk of pneumonia in children under five in Klaten, Central Java. Journal of Epidemiology and Public Health. 03(02): 128-142. https://doi.org/10.26911/jepublichealth.2018.03.02.03

Machmud R (2009). Pengaruh kemiskinan keluarga pada kejadian pneumonia balita di Indonesia (The effect of family poverty on the incidence of children under five pneumonia in Indonesia). Kesmas: National Public Health Jour- nal. 4(1): 36. https://doi.org/10.21109/kesmas.v4i1.199

Mosley WH, Chen LC (2003). Extracted from: Population and Development Review 1984; 10: 25-45. Bull World Health Organ. 81(2): 140-145

Mustikarani YA, Rahardjo SS, Qadridjati I, Prasetya H (2019). Contextual effect of village on the risk of pneumonia in children under five in Magetan, East Java. Journal of Epidemiology and Public Health. 4(2): 117-126.https://doi.org/10.26911/jepublichealth.2019.04.02 .07

Nguyen TKP, Tran TH, Roberts, CL, Graham SM, Marais BJ (2017). Child pneumonia-focus on the Western Pacific Region.Paediatric Respiratory Reviews, 21. 102-110. https://doi.org/10.1016/j.prrv.2016.07.004

Nikmah A, Rahardjo SS, Qadrijati I (2018). Indoor smoke exposure and other risk factors of pneumonia among children under five in Karanganyar, Central Java. Journal of Epidemiology and Public Health. 03(01): 25-40. https://doi.org/10.26911/jepublichealth.2018.03.01.03

Norbäck D, Lu, C, Zhang Y, Li B, Zhao Z, Huang C, Deng Q (2019). Sources of indoor particulate matter (PM) and outdoor air pollution in China in relation to asthma, wheeze, rhinitis and eczema among pre-school children: Synergistic effects between antibiotics use and PM 10 and second hand smoke. Environment International. 125: 252-260. https://doi.org/10.1016/j.envint.2019.01.036

Nugroho SP (2018). Korban Meninggal akibat gempa lombok menjadi 515 orang (died earthquake victims in Lombok were 515 people). https://nasional.kompas.com/read/2018/o8/2 1/15522321/korban-meninggal-akibat- 
Journal of Epidemiology and Public Health (2019), 4(3): 234-246

https://doi.org/10.26911/jepublichealth.2019.04.03.11

gempa-lombok-menjadi-515-orang

Pekey B, Bozkurt ZB, Pekey H, Doĝan G, Zararsiz A, Efe N, Tuncel G (2010). Indoor/outdoor concentrations and elemental composition of PM10/PM2.5 in urban/industrial areas of Kocaeli City, Turkey. Indoor Air. 20(2): 112125. https://doi.org/10.1111/j.1600-0668.2009.00628.x

Pradhan S, Rao A, Pattanshetty S, Nilima A (2016). Knowledge and perception regarding childhood pneumonia among mothers of under-five children in rural areas of Udupi Taluk, Karnataka: A cross-sectional study. Indian Journal of Health Sciences, 9(1): 35. https://doi.org/10.4103/2349-5006.183690

PrayGod G, Mukerebe C, Magawa R, Jeremiah K, Török ME (2016). Indoor air pollution and delayed measles vaccination increase the risk of severe pneumonia in children: Results from a Case-control study in Mwanza, Tanzania. PLoS ONE, 11(8): 1-13. https://doi.org/10.1371/journal.pone.0160804

Provinsi NTB (2018). Profil Kesehatan Provinsi Nusa Tenggara Barat Tahun 2017 (Health Profile of the Province of
West Nusa Tenggara in 2017). 192

Ramezani M, Aemmi ZS, Moghadam ZE (2015). Factors affecting the rate of pediatric pneumonia in developing countries: a Review and literature study. Review Article. 3(24): 11731181. Retrieved from http://ijp.mums.ac.ir.

UU No 24 th 2007 Tentang Penanggulangan Bencana.

WHO (2014). Retrieved from https://www.who.int/topics/pneumococcal_infections/en/Retrieved from http://www.ncbi.nlm.nih.gov/pubmed/25823620

Yunita A, Murti B, Dewi YLR (2017). Multilevel analysis on the bio-psychosocial and environment factors affecting the risk of pneumonia in infants. Journal of Epidemiology and Public Health 01(01): 1-10. https://doi.org/10.26911/jepublichealth.2016.01.01.01.

Zhou W, Zuo X, Li J, Yu Z (2016). Effects of nutrition intervention on the nutritional status and outcomes of pediatric patients with pneumonia. Minerva Pediatrica. 68(1): 5-10. Retrieved from http://www.ncbi.nlm.nih.gov/pubmed /25823620. 